\title{
MODEL PENILAIAN OTENTIK DALAM PEMBELAJARAN BAHASA
}

\author{
Burhan Nurgiyantoro dan Pujiati Suyata \\ Fakultas Bahasa dan Seni Universitas Negeri Yogyakarta \\ email: burhan@uny.ac.id
}

\begin{abstract}
This study aims to produce a validated guidebook for Authentic Assessment in Language Learning. The research activities included the guidebook development and the product was validated by three assessment experts and five teachers as stakeholders. The validation was conducted through a questionnaire and a feedback sheet and the results were used to revise the draft to produce the final guidebook. The guidebook consists of the front page, three main chapters, references, a glossary, and an index. The results of the validation show that the guidebook is good. Conceptually it is dependable and as a guidebook it is relatively easy to use in language learning activities at school. According to the validators, it is useful to improve the language learning quality.
\end{abstract}

Keywords: authentic assessment, language learning, validation

\section{PENDAHULUAN}

Kegiatan penilaian merupakan bagian tidak terpisahkan dari kegiatan pembelajaran secara keseluruhan. Lewat penilaian itu dapat diperoleh informasi tentang seberapa baik keberhasilan peserta didik belajar dan guru (dosen) membelajarkan peserta didik, dan karenanya ia sekaligus dapat berfungsi sebagai umpan-balik. Dalam kaitan ini penilaian dapat dipandang sebagai kontrol kualitas kegiatan pembelajaran yang dilaksanakan. Oleh karena itu, penilaian harus mendapat perhatian yang secukupnya dalam proses pembelajaran.

Perkembangan di seputar pendekatan penilaian hasil pembelajaran peserta didik sejalan dengan perkembangan kurikulum yang dipergunakan. Hal itu disebabkan penilaian merupakan salah satu komponen yang terkait langsung dengan kurikulum. Penilaian hasil pembelajaran merupakan bagian dari kurikulum, bagian dari pelaksanaan pendidikan secara keseluruhan. Maka, pengembangan sistem evaluasi hasil pembelajaran haruslah sudah dirancang bersamaan dengan pengembangan suatu kurikulum sehingga terjadi keselarasan dengan komponen kurikulum yang lain. Lewat penilaian itu dapat diperoleh informasi tentang seberapa baik keberhasilan peserta didik belajar dan guru (dosen) membelajarkan peserta didik (mahassiwa), dan karenanya ia sekaligus dapat berfungsi sebagai umpan balik. Artinya, berdasarkan informasi dari penilaian itu dapat dilakukan "peninjauan kembali" terhadap kurikulum yang bersangkutan. Dalam kaitan ini penilaian dapat dipandang sebagai kontrol kualitas kegiatan pembelajaran yang dilaksanakan. Oleh karena itu, penilaian harus mendapat perhatian yang secukupnya dalam proses pembelajaran apa pun kurikulum yang dilaksanakan.

Kurikulum itu sendiri adalah seperangkat rencana dan pengaturan mengenai tujuan, isi, dan bahan pelajaran serta cara yang digunakan sebagai pedoman penyelenggaraan kegiatan pembelajaran untuk mencapai tujuan 
tertentu (PP No.19, Th. 2005:3). Untuk mengukur kadar ketercapaian kurikulum di jejang sekolah, khususnya yang mencakup tujuan dan isi, penilaian terhadap capaian hasil pembelajaran mesti dilakukan. Tiap kurikulum lazimnya memiliki fokus-fokus capaian tertentu yang membedakannya dengan kurikulum sebelumnya. Hal itu tentu membawa dampak bagi pelaksanaan pembelajaran dan penilaian yang dilakukan di sekolah.

Dewasa ini kurikulum yang dipergunakan di dunia pendidikan di Indonesia adalah kurikulum yang berbasis kompetensi, baik dengan nama Kurikulum Berbasis Kompetensi (KBK) maupun yang kemudian bernama Kurikulum Tingkat Satuan Pendidikan (KTSP). KBK mulai dilaksanakan di sekolah di Indonesia pada tahun ajaran 2004 dan KTSP tahun 2006/2007. Seringnya terjadi pergantian dan atau perubahan kurikulum pada hakikatnya merupakan reaksi pemerintah akibat terjadinya kemajuan dan perkembangan ilmu pengetahuan dan teknologi yang demikian cepat sehingga terjadi pergeseran kebutuhan dan tuntutan di masyarakat terhadap dunia pendidikan. Pada hakikatnya hal itu juga sekaligus merupakan salah satu indikator capaian keberhasilan pendidikan yang mengidealkan kemajuan dan kedinamisan masyarakat sesuai dengan perkembangan zaman.

Dalam kurikulum yang berbasis kompetensi sebagaimana yang dipergunakan di dunia pendidikan di Indonesia - yang bernama Kurikurikulum Tingkat Satuan Pendidikan (KTSP) menempatkan penilaian menempati posisi penting. Ada tiga fokus utama dalam pengembangan kurikulum berbasis kompetensi, yaitu penentuan kompetensi, pengembangan silabus, dan pengembangan penilaian. Komponen penilaian diyakini memberikan dampak nyata bagi keberhasilan pembelajaran kompetensi kepada peserta didik, maka penilaian kini ditempatkan pada posisi yang penting dalam rangkaian kegiatan pembelajaran. Bentuk dan cara penilaian dalam banyak hal memberikan pengaruh penting bagi proses pembelajaran, bagaimana guru harus membelajarkan dan bagaimana peserta didik harus belajar, dan karenanya menentukan capaian kompetensi.

KTSP merekomendasikan penggunaan pendekatan Contextual Teaching and Learning (CTL, pendekatan kontekstual) sebagai salah satu metode pembelajaran yang dipakai di sekolah. Pada prinsipnya pendekatan ini menekankan pentingnya pengaitan antara materi ajar yang dibelajarkan di kelas dan realitas faktual yang secara konkret ada di lingkungan masyarakat di mana peserta didik menjadi bagian. Dengan cara itu diharapkan terdapat kesesuaian antara apa yang dipelajari peserta didik di sekolah dan kemanfaatannya dengan kebutuhan hidup secara nyata. Di sekolah peserta didik dibantu untuk membangun keterkaitan antara informasi (pengetahuan) baru dan pengalaman (pengetahuan lain) yang telah mereka miliki dan juga dibelajarkan bagaimana mempelajari konsep serta bagaimana konsep tersebut dapat dipergunakan di luar kelas.

Penilaian otentik (authentic assessment) merupakan model penilaian yang sejalan dengan pendekatan kontekstual. Penilaian otentik menekankan pengukuran hasil pembelajaran yang berupa kompetensi peserta didik untuk melakukan sesuatu, bukan sekadar mengetahui sesuatu, sesuai dengan mata pelajaran dan kompetensi yang dibelajarkan. Tekanan capaian kompetensi bukan pada pengetahuan yang dikuasai peserta didik, melainkan pada kemampuan peserta didik untuk menampilkan, mendemonstrasikan, atau melakukan sesuatu yang merupakan cerminan esensi 
pengetahuan dan kemampuan yang telah dikuasainya tersebut. Kompetensi untuk melakukan sesuatu tersebut haruslah sesuatu yang dibutuhkan dalam kehidupan, misalnya dalam dunia pekerjaan.

Jadi, dalam asesmen otentik peserta didik diukur kompetensinya menampilkan pengetahuan, kemampuan, dan keterampilan yang kesemuanya itu harus bermakna (meaningful). Istilah bermakna dimaksudkan ada kaitannya atau kesesuaiannya dengan kebutuhan hidup secara nyata. Peserta didik haruslah dilatih dan ditantang agar dapat menggunakan informasi akademis baru dan keterampilan yang dipelajari di kelas ke dalam situasi nyata di masyarakat untuk tujuan yang signifikan dengan kebutuhan hidup. Hal itu sejalan dengan prinsip penilaian otentik yang merupakan kinerja dan sekaligus harus bermakna. Sebagaimana dikatakan Mueller (2008) penilaian otentik merupakan suatu bentuk tugas yang menghendaki pembelajar untuk menunjukkan kinerja di dunia nyata secara bermakna yang merupakan penerapan esensi pengetahuan dan keterampilan.

Penilaian otentik merupakan penilaian terhadap tugas-tugas yang menyerupai kegiatan membaca dan menulis sebagaimana halnya di dunia nyata dan di sekolah. Tujuan penilaian itu adalah untuk mengukur berbagai keterampilan dalam berbagai konteks yang mencerminkan situasi di dunia nyata di mana keterampilan-keterampilan tersebut digunakan. Misalnya, penugasan kepada pembelajar untuk membaca berbagai teks aktual-realistik, menulis topik-topik tertentu sebagaimana halnya di kehidupan nyata, dan berpartisipasi konkret dalam diskusi atau bedah buku, menulis untuk jurnal, surat, atau mengedit tulisan sampai siap cetak. Dalam kegiatan itu, baik materi pembela- jaran maupun penilaiannya terlihat atau bahkan memang alamiah.

Jadi, penilaian model ini menekankan pada pengukuran kinerja, melakukan sesuatu yang merupakan penerapan ilmu pengetahuan yang telah dikuasai secara teoretis. Penilaian otentik menuntut pembelajar mendemonstrasikan pengetahuan, keterampilan, dan strategi dengan mengreasikan jawaban atau produk. Siswa tidak sekadar diminta merespon jawaban seperti dalam tes tradisional, melainkan dituntut untuk mampu mengreasikan dan menghasilkan jawaban yang dilatarbelakangi oleh pengetahuan teoretis. Dalam penilaian kemampuan bersastra misalnya, pembelajar mampu menganalisis karakter tokoh dalam sebuah fiksi, memertanggungjawabkan kinerjanya tersebut secara argumentatif, membuat resensi teks kesastraan, dan lain-lain.

Masalah kinerja, performansi, demonstrasi, atau apalah istilahnya, tentulah dalam pengertian sesuai dengan karakteristik masing-masing mata pelajaran. Tiap mata pelajaran tentu memiliki kriteria kinerja yang belum tentu sama dengan mata-mata pelajaran yang lain. Kinerja hasil pembelajaran bahasa tentu tidak sama dengan hasil pembelajaran matematika, teknik otomotif, tata busana, seni musik, dan lain-lain. Namun, pada prinsipnya semua mata pelajaran itu haruslah melaksanakan penilaian dan salah satunya dengan model penilaian otentik. Walau tiap mata pelajaran berbeda karakteristik, baik yang termasuk kategori ilmu-ilmu eksakta maupun sosial dan humaniora, kesemuanya tampaknya dapat menerapkan model penilaian otentik khususnya yang berupa portofolio.

Depdiknas (2006) menunjukkan sejumlah strategi atau jenis penilaian otentik yang dapat dilakukan yang antara lain adalah penilaian kinerja, observasi sistematik, pertanyaan terbuka, 
portofolio, penilaian pribadi, dan jurnal.

Kurikulum sekolah yang berlaku sebelum ini terlihat kurang memaksimalkan evaluasi dalam pelaksaaan pembelajaran bahasa di sekolah, khususnya sebagaimana yang dimaksudkan oleh asesmen otentik. Berdasarkan pengamatan sepintas terlihat bahwa para guru juga tidak termotivasi dan tertantang untuk secara kreatif mengembangkan evaluasi pembelajaran sehingga kegiatan evaluasi yang dilakukan kurang mengikuti tuntutan pembelajaran dewasa ini. Hal itu juga terlihat dalam hal penilaian pembelajaran bahasa dan sastra. Ketika KTSP merekomendasikan penggunaan pendekatan CTL dan asesmen otentik, terlihat bahwa guru kurang siap menyambut pelaksanaan kedua hal tersebut dalam pelaksanaan pembelajaran di kelas. Hal itu terlihat, misalnya pada kegiatan pelatihan (PLPG) sertifikasi guru.

Idealnya terjadi kesejajaran antara kompetensi yang akan dicapai, bahan dan strategi, dan evaluasi hasil pembelajaran. Secara umum tujuan pembelajaran bahasa Indonesia di sekolah menengah (SMP dan SMA) adalah capaian kemampuan berkomunikasi lewat saluran keempat kemampuan berbahasa, maka evaluasi yang dilakukan juga haruslah mengukur kemampuan berbahasa itu yang dalam kaitan ini adalah penilaian otentik. Penilaian otentik menekankan penilaian pada kemampuan berunjuk kerja bahasa (kompetensi berbahasa, kompetensi komunikatif) sebagaimana halnya dalam berkomunikasi sehari-hari untuk berbagai keperluan dan bukan sekadar mengungkap pengetahuan bahasa (kompetensi linguistik). Pengembangan model penilaian otentik adalah sebuah keharusan demi peningkatan kualitas pembelajaran dan sekaligus memaksimalkan pelaksanaan kurikulum (KTSP) serta capaian hasil pembelajaran bahasa Indonesia.
Penelitian ini merupakan tahap kedua tahun kedua dengan target terselesaikannya penulisan buku panduan panduan Model Penilaian Otentik dalam Pembelajaran Bahasa. Ada pun secara khusus tujuan penelitian untuk tahun tahun kedua (2010) adalah (1) tersusunnya buku panduan Model Penilaian Otentik dalam Pembelajaran Bahasa, dan (2) tervalidasikanya produk buku panduan yang dimaksud baik oleh pakar penilaian bahasa maupun guru mata pelajaran Bahasa Indonesia di DIY selaku pemangku kepentingan.

\section{METODE}

Penelitianpengembanganinididesain dengan memergunakan prosedur sebagaimana yang dikemukakan oleh Borg dan Gall (1983) dan dilakukan dalam dua tahap selama dua tahun. Pada tahap pertama tahun pertama ada dua kegiatan pokok yang dilakukan, yaitu survei lapangan dan kajian pustaka pendukung pengembangan produk sebagaimana telah dituliskan dalam jurnal sebelumnya. Kegiatan penelitian tahap kedua tahun kedua yang kini dilaporkan, difokuskan pada pengembangan buku panduan yang menjadi tujuan utama penelitian ini. Selain berdasarkan penerapan konsep asesmen otentik, penulisan buku yang dimaksud juga memertimbangkan masukan dari sejawat dan guru. Draf buku panduan penilaian yang dihasilkan divalidasikan kepada sejawat pakar penilaian dan guru selaku pemangku kepentingan. Masukan dan saran dari kedua kelompok validator tersebut dipergunakan untuk memerbaiki draf buku sehingga menghasilkan buku panduan final yang dikembangkan.

Validator adalah kelompok dosen pakar penilaian (tiga orang) dan kelompok guru SMP mata pelajaran Bahasa Indonesia (lima orang) masing-masing adalah ketua MGMP kota madya Yog- 
yakarta Daerah Istimewa Yogyakarta dan keempat kabupaten (Kabupaten Bantul, Sleman, Kulonprogo, dan Gunung Kidul). Kepada para validator diminta membaca draf buku panduan dan kemudian diminta mengisi angket serta memberikan saran dan masukan. Pengumpulan data dilakukan dengan pemberian angket dan lembar saran. Para validator diminta membaca draft buku panduan dan diberi angket serta lembar saran.

Angket yang dikembangkan ada meliputi angket tertutup dan disertai lembar saran agar para validator bebas menuliskan apa yang diharapkan yang belum tercakup dalam pada angket. Angket untuk pakar penilaian berkaitan dengan ketepatan konsep asesmen otentik dan penerapannya dalam pengukuran berbagai keterampilan berbahasa yang seluruhnya berjumlah sepuluh buah pertanyaan. Angket untuk guru berkaitan dengan ketepatan model asesmen dan kepraktisannya untuk diterapkan dalam penilaian hasil pembelajaran yang jumlahnya juga sepuluh butir pertanyaan. Pilihan jawaban untuk angket berupa skala 1-4 yang bersifat gradasi semakin meningkat; 1: kurang, 2: sedang, 3: baik, dan 4: amat baik. Sebelum diberikan kepada para validator, instrumen yang dimaksud telah diujicobakan kepada anggota tim untuk mendapatkan kepastian ketepatan isi dan redaksional.

Data penelitian adalah data validasi hasil pengembangan buku panduan. Data angka dari angket dianalisis dengan teknik penghitungan persentase, sedang data verbal dianalisis dengan teknik kategorisasi dan pembuatan inferensi. Hasil penilaian para validator lewat angket menunjukkan "kualitas" draf buku panduan yang dikembangkan oleh validator. Masukan yang berupa saran menunjukkan harapan para validator tentang buku panduan agar lebih baik. Saran dan masukan dipakai untuk memerbaiki darf buku panduan menjadi buku panduan final sebagai hasil penelitian pengembangan ini.

\section{HASIL DAN PEMBAHASAN Produk Buku Panduan}

Sesuai dengan tujuan akhir penelitian pengembangan ini, produk pengembangan berupa buku panduan yang diberi judul Model Penilaian Otentik dalam Pembelajaran Bahasa. Buku dikembangkan dengan mengacu pada Model Silabus dan Rencana Pelaksanaan Pembelajaran Mata Pelajaran Bahasa Indonesia SMP/MTs. Contoh penerapan tugas-tugas otentik sengaja berangkat dari standar kompetensi (SK) dan kompetensi dasar (KD) yang tercantum dalam buku tersebut. Hal itu dimaksudkan agar pembicaraan menjadi lebih konkret, praktis, dan mudah diikuti karena guru tentu tidak merasa asing.

Tidak berbeda halnya dengan penilaian model yang lain, pengembangan model penilaian otentik secara konkret berangkat dari indikator yang dijabarkan dari KD. Indikator merupakan petunjuk langsung tentang capaian kompetensi oleh peserta didik terhadap kompetensi yang dibelajarkan. Pembuatan indikator sebagaian mengambil dari contoh kurikulum dan sebagian yang lain dikembangkan sendiri. Dalam kegiatan pembelajaran guru memiliki tugas dan wewenang untuk mengembangkan indikator pembelajaran sendiri, namun harus mencerminkan KD tertentu yang diacu.

Kompetensi pembelajaran yang dikembangkan ke model penilaian otentik meliputi kompetensi kebahasaan, menyimak, membaca, berbicara, menulis, dan bersastra. Tiap kompetensi dicontohkan untuk dua KD dan tiap KD dijabarkan menjadi tiga buah indikator. KD dan indikator yang dipilih dan dikembangkan sengaja dibuat yang ber- 
beda karena dimaksudkan untuk memberikan berbagai variasi dalam pembuatan tugas-tugas otentik. Sesuai dengan semangat KTSP yang memberikan kebebasan kreativitas kepada para guru, pengembangan penilaian otentik juga memberikan kebebasan yang serupa baik dalam hal memilih indikator, tugas, maupun pembuatan rubrik penilaian.

Penelitian pengembangan ini menghasilkan produk buku panduan yang diberi judul Model Penilaian Otentik dalam Pembelajaran Bahasa yang diterbitkan menjadi sebuah buku yang dapat dijadikan sebagai salah satu acuan dalam kegiatan penilaian pembelajaran bahasa di sekolah.

\section{Validasi Produk Buku Panduan}

Setelah draf buku panduan selesai disusun dan dikaji ulang, kegiatan berikutnya adalah memvalidasikan produk tersebut kepada pihak-pihak tertentu yang terkait yang dipandang dapat memberikan masukan untuk penyempurnaan. Ada dua kelompok pihak yang dipilih untuk menvalidasi produk, yaitu kelompok pakar (dosen perguruan tinggi) dan kelompok guru mata pelajaran Bahasa Indonesia SMP (para ketua MGMP di Daerah Istimewa Yogyakarta).

Pakar evaluasi pembelajaran bahasa yang diminta untuk memberikan validasi adalah dua orang dosen bahasa Indonesia dan seorang bahasa Inggris lewat pemberian angket dan permintaan saran dan atau masukan. Hasil penilaian terhadap produk buku panduan lewat angket oleh ketiga pakar tersebut adalah sebagai berikut. Rata-rata skor terhadap pernyataan angket adalah: pakar $\mathrm{I}=3,90$, pakar $\mathrm{II}=3,80$, pakar $\mathrm{III}=4,00$, dan rata-rata keseluruhan 3,90. Dengan demikian, dapat disimpulkan bahwa rata-rata skor yang diberikan cukup tinggi (sedikit di bawah amat baik). Hal itu dapat diartikan bahwa menurut mereka konsep teoretis produk buku panduan yang divalidasikan cukup valid.

Adapun saran dan masukan yang diberikan oleh ketiga pakar dapat dirangkum sebagai berikut. (1) Penggunaan istilah yang terdapat di dalam aspek rubrik sebaiknya konsisten , misalnya dengan diksi. (2) Perbaikan kesalahan penghitungan jumlah skor maksimal dalam contoh tugas yang diberikan dalam tugas otentik kosakata. (3) Penulisan secara eksplisit nama-nama model/ jenis penilaian otentik pada penerapan penilaian otentik. (4) Proporsi jumlah halaman tiap bab perlu dipertimbangkan, kalau perlu dibuat bab-bab baru untuk tiap penerapan penilaian otentik kompetensi berbahasa dan bersastra. (5) Buku ini amat dinantikan para guru.

Guru mata pelajaran bahasa Indonesia yang diminta untuk memberikan validasi buku panduan ada lima orang, dan hasilnya adalah sebagai berikut. Rata-rata skor terhadap pernyataan angket adalah: guru $\mathrm{I}=3,60$, guru $\mathrm{II}=3,80$, guru $\mathrm{III}=3,70$, guru $\mathrm{IV}=3,60$, guru $\mathrm{V}=3,30$, dan rata-rata keseluruhan 3,60. Dengan demikian, dapat disimpulkan bahwa rata-rata skor yang diberikan masih cukup tinggi (sedikit di atas pertengahan antara baik dan amat baik). Hal itu dapat diartikan bahwa menurut para guru yang sebagai calon pengguna, produk buku panduan yang divalidasikan dapat secara mudah dilaksanakan untuk mengukur kompetensi berbahasa peserta didik dalam proses pembelajaran di kelas.

Adapun saran dan masukan yang diberikan oleh kelima guru mata pelajaran Bahasa Indonesia dapat dirangkum sebagai berikut. (1) Judul buku ditambah menjadi Model Penilaian Otentik dalam Pembelajaran Bahasa Indonesia. (2) Rentang nilai menggunakan skala 1-100 saja agar sesuai dengan buku rapor. (3) Bahasa dan penyajian enak dan mudah diikuti; bahasanya mengalir 
ringan membantu pembaca untuk memahami; banyak memergunakan kata bentukan baru yang belum familier, walau itu benar tetapi mengapa tidak dari dulu-dulu; khusus untuk diksi agak sulit dipahami oleh guru-guru tertentu, misalnya guru SD, guru di pelosok, menengah ke bawah. (4) Konsistensi contoh tugas otentik, ada yang satu KD dan ada dua KD dengan beberapa indikator; bagaimana jika satu KD dengan beberapa indikator. (5) Ketepatan rubrik penilaian perlu dipertimbangkan; bisa dengan rubrik lain yang memertimbangkan bobot tiap aspek. (6) Buku ini bagus dan sangat dibutuhkan, membantu pemahaman karena ada glosarium; mohon pendistribusiannya ke sekolah-sekolah merata.

\section{PEMBAHASAN}

Buku panduan mengenai penilaian otentik dalam pembelajaran bahasa yang dikembangkan ini dimaksudkan untuk menjawab tantangan kebutuhan model penilaian sebagaimana disarankan penggunaannya dalam kurikulum. Penggunaan model penilaian otentik merupakan konsekuensi dari penggunaan pendekatan pembelajaran kontekstual (CTL,Contextual Teaching and Learning, lihat Johnson, 2006) dalam pelaksanaan pembelajaran. Artinya, jika pelaksanaan pembelajaran menggunakan pendekatan pembelajaran kontekstual, model penilaian yang sesuai dengan pendekatan tersebut adalah penilaian otentik. Hal itu disebabkan adanya persamaan karakteristik antara pendekatan pembelajaran kontekstual yang menuntut pelibatan konteks dan keaktifan peserta didik dan penilaian otentik yang menekankan kinerja dan bermakna (Meller, 2008).

Menurut Callison (2009) asesmen otentik merupakan sebuah penilaian proses yang di dalamnya melibatkan berbagai kinerja yang mencerminkan bagaimana peserta didik belajar, capaian hasil, motivasi, dan sikap yang terkait dengan aktivitas pembelajaran. Asesmen otentik yang menekankan kinerja berasumsi bahwa ada sekian banyak unjuk kerja yang dapat ditampilkan peserta didik selama berlangsungnya kegiatan pembelajaran yang kesemuanya itu lebih luas dari sekadar ujian tertulis jawaban singkat sebagaimana dalam tes tradisional. Berbagai hasil pembelajaran yang ditampilkan dan didemonstrasikan peserta didik yang sekaligus mencerminkan situasi kehidupan nyata, dan karenanya lebih bermakna, itulah yang ditampung dalam wadah asesmen otentik sehingga kinerja peserta didik tersebut juga dapat diperhitungkan sebagai hasil pembelajaran yang harus juga diberi nilai.

Penilaian otentik sebenarnya telah lama dikenal di dunia pendidikan, tetapi baru naik daun di era KTSP. Sebenarnya, bentuk-bentuk penilaian otentik bukan merupakan barang asing bagi para pendidik di Indonesia karena sebagian (baik sebagai pelaku maupun pemilihan bentuk) telah melakukan penilaian model itu. Hanya memang pada umumnya kita lebih akrab dengan penilaian model tradisional. Penilaian tradisional dalam kaitan ini dilihat sebagai penilaian yang lebih banyak menyadap pengetahuan yang telah dikuasai siswa sebagai hasil belajar yang pada umumnya ditagih lewat bentuk-bentuk tes objektif. Di pihak lain, penilaian otentik lebih menekankan pada pemberian tugas yang menuntut pembelajar menampilkan, memraktikkan, atau mendemonstrasikan hasil pembelajarannya di dunia nyata secara bermakna yang mencerminkan penguasaan pengetahuan dan keetrampilan dalam suatu mata pelajaran. Singkatnya, penilaian tradisional lebih menekankan tagihan penguasaan pengetahuan, sedang penilaian otentik kinerja atau tampilan 
yang mencerminkan penguasaan pengetahuan dan keterampilan.

Selain hal-hal di atas, hal lain yang membedakan kedua jenis penilaian tersebut, jika dibuat secara pilah dikotomis, adalah berupa perbedaan antara: (i) memilih jawaban dan menunjukkan suatu aktivitas, (ii) menunjukkan penguasaan pengetahuan dan demonstrate proficiency by doing something, (iii) memanggil kembali atau rekognisi dan mengonstruksi atau aplikasi, (iv) soal dan jawaban disusun guru dan peserta didik menyusun sendiri jawaban, dan (v) bukti tidak langsung dan bukti langsung (faktual).

Perbedaan utama dalam penilaian tradisional yang lazim memergunakan bentuk tes objektif pilihan ganda, peserta didik "hanya" diminta merespon atau menanggapi sejumlah pilihan (lazimnya empat pilihan) sebagai yang diperintahkan dalam pokok soal. Peserta didik "hanya" memilih jawaban, sedang yang membuat jawaban, baik yang benar maupun yang salah yang berfungsi sebagai butir-butir pengecoh adalah guru atau pembuat soal. Peserta didik tidak dapat memilih jawaban lain selain yang telah disediakan. Di pihak lain dalam penilaian otentik, peserta didik dituntut untuk mengonstruksi jawaban sendiri. Istilah mengonstruksi dapat berarti memilih, menampilkan, menerapkan, membuat, mengembangkan, dan lainlain yang pada intinya harus menunjukkan kinerja. Dalam ranah tes berbahasa, kinerja berarti secara aktif produktif menghasilkan bahasa yang bermakna, bahasa sebagaimana fungsinya dalam kehidupan sehari-hari.

Model penilaian yang dikembangkan dalam buku panduan telah diusahakan memenuhi tuntutan penilaian otentik. Ujian-ujian bahasa yang lazim "hanya" berupa tagihan pemahaman atau bahkan tagihan pengetahuan tentang bahasa diusahakan diubah menjadi menyusun jawaban sendiri oleh peserta didik. Jawaban ujian harus berupa kinerja berbahasa yang aktif produktif baik lewat saluran lisan (berbicara) maupun tulisan (menulis), dan semuanya harus bermakna. Misalnya, ujian kompetensi menyimak dan membaca, bahkan juga pengetahuan kosakata dan struktur diubah menjadi ujian yang membutuhkan jawaban yang dibuat sendiri oleh peserta didik yang mencerminkan kompetensi pemahaman dan pengetahuannya. Jadi, pada intinya semua tugas otentik harus memaksa peserta didik untuk menyusun atau mengonstruksi sendiri jawaban.

Tugas-tugas otentik yang dicontohkan bermacam-macam walau tidak mencakup semua tugas otentik yang jenisnya relatif banyak. Tugas itu antara lain berupa menceritakan kembali secara lisan atau tertulis, menjawab pertanyaan terbuka, membuat bermacam-macam tulisan yang dibutuhkan di dunia nyata, mengedit dan memerbaiki tulisan, dan lain-lain. Guru sebagai pelaksana pembelajaran di sekolah diharapkan dapat memilih dan menambah sendiri tugas-tugas yang relevan sesuai dengan kompeetnsi yang dibelajarkan. Jika model yang dicontohkan kurang banyak atau kurang bervariasi, hal itu dimaksudkan agar guru mengreasikan sendiri model-model yang diinginkan karena pada bagian awal buku panduan juga sudah diuraikan perihal penilaian otentik termasuk macam-macam tugasnya.

Misalnya, tes kosakata dan struktur kalimat yang selama ini hampir pasti berupa tes tagihan pengetahuan lewat tes tradisional, di buku panduan dicontohkan menjadi tugas mengoreksi karangan sebagaimana halnya yang dilakukan oleh guru ketika memeriksa pekerjaan peserta didik atau redaktur majalah yang memeriksa artikel. Tugas berupa menemukan bentuk kebahasaan 
(kosakata, struktur kalimat, dan ejaan) yang salah (sengaja dibuat salah) dalam sebuah wacana, dan kemudian peserta didik diminta untuk membetulkan. Setiap kali mereka dapat menemukan dan membetulkan kesalahan dengan benar ada skornya. Pemilihan tugas ersebut benar-benar otentik karena kerja seperti itu dibutuhkan di dunia kerja dan sekaligus membutuhkan kompetensi kebahasaan. Untuk dapat mengerjakan tugas dengan benar, hal itu diprasyarati pengetahuan yang memadai tentang sistem bahasa. Namun, model ujian bukan tes tentang sistem itu secara tersendiri, melainkan langsung penerapannya dalam wacana.

Selain itu, semua tugas yang dicontohkan dalam buku panduan sengaja berangkat dari SK (standar kompetensi), dan KD (kemampuan dasar), dan beberapa contoh indikator yang terdapat di dalam kurikulum SMP/MTs (Depdiknas, 2006). Hal itu dilakukan agar buku tersebut dapat dipraktikkan secara langsung, dan dengan pengembangan sendiri oleh para guru, karena telah sesuai dengan kurikulum yang dilaksanakan. Namun, indikator tidak harus sesuai dengan contoh yang ada. KTSP (Kurikulum 2006) memberikan kebebasan kreativitas kepada guru untuk mengembangkan sendiri indikator hasil pembelajaran. Jadi, contoh-contoh yang diberikan memang berfungsi sekedar contoh. Maka, di sinilah antara lain terlihat kompetensi guru dalam kegiatan pembelajaran.

Walau buku panduan ini dikembangkan berdasarkan silabus kurikulum SMP/ MTs, ia tidak menutup kemungkinan dipergunakan sebagai model penilaian otentik untuk SMA, MAN, atau yang sederajat, bahkan juga untuk panduan pembelajaran bahasa-bahasa yang lain seperti bahasa Inggris dan bahasa Daerah dengan penyesuaian. Konsep penilaian otentik dapat dipergunakan untuk berbagai mata pelajaran, bahkan yang di luar mata pelajaran bahasa. Jadi, jika model penilaian otentik yang dikembangkan untuk mata pelajaran Bahasa Indonesia SMP/MTs ini secara relatif tidak jauh berbeda untuk diterapkan dalam mata pelajaran bahasa yang lain.

Model penilaian otentik berupa tugas-tugas kinerja berbahasa secara aktif produktif, maka dalam hal penyekoran menuntut pemilihan model yang sejenis. Artinya, penilaian dan atau penyekoran kinerja haruslah dipilih model yang sesuai. Model penyekoran yang lazim dipergunakan adalah memergunakan rubrik. Rubrik merupakan skala penyekoran yang dipergunakan untuk menilai kinerja subjek didik untuk tiap kriteria terhadap tugas-tugas tertentu (Mueller, 2008). Rubrik dipergunakan untuk menentukan tinggi rendahnya capaian kinerja peserta didik. Dalam sebuah rubrik terdapat dua hal pokok yang harus dibuat, yaitu kriteria dan tingkat capaian kinerja tiap kriteria. Kriteria berisi hal-hal esensial yang ingin diukur tingkat capaian kinerjanya yang secara esensial dan konkret mewakili kompetensi yang diukur capaiannya. Kriteria haruslah dirumuskan atau dinyatakan singkat padat, komunikatif, dengan bahasa yang gramatikal, dan benar-benar mencerminkan kompetensi yang diukur. Dalam sebuah rubrik, kriteria mungkin saja dilabeli dengan katakata tertentu yang lebih mencerminkan isi, misalnya dengan kata-kata: unsur yang dinilai.

Tingkat capaian kinerja umumnya ditunjukkan dalam angka-angka, dan yang digunakan dalam buku panduan adalah $1-5$. Tiap angka tersebut mempunyai deskripsi verbal yang diwakili, skor 1: tidak ada kinerja atau kinerja tidak tepat sama sekali, skor 5: kinerja sangat meyakinkan dan bermakna, sedang skor 2, 3, dan 4 secara 
berurut-turut menunjukkan semakin baiknya kinerja dan kebermaknaannya. Bunyi deskripsi verbal haruslah sesuai dengan rubrik yang akan diukur. Penilaian tingkat capaian kinerja seorang pembelajar dilakukan dengan menandai angka-angka yang sesuai. Rubrik lazimnya ditampilkan dalam tabel, kriteria ditempatkan di sebelah kiri dan tingkat capaian di sebelah kanan tiap kriteria. Jadi, rubrik dibuat secara analitis, yaitu yang menunjuk pada rubrik yang memberikan penilaian tersendiri untuk tiap kriteria (Mueller, 2008).

Selain daftar pustaka yang merupakan komponen wajib, buku panduan ini juga dilengkapi dengan glosarium dan indeks. Adanya glosarium dimaksudkan untuk memudahkan guru atau pengguna lain yang bermaksud memahami arti tiap istilah yang dipergunakan, sedang indeks untuk memudahkan menemukan di halaman berapa sebuah nama atau istilah dipakai.

Hasil validasi baik yang diberikan oleh pakar penilaian maupun guru SMP menunjukkan bahwa buku panduan yang dikembangkan baik. Ratarata keseluruhan yang diperoleh dari penilaian pakar adalah 3,90, sedang dari guru 3,60. Validasi untuk pakar lebih terkait dengan aspek konseptual penilaian otentik, sedang untuk guru terkait dengan aspek kepraktisan penerapannya di kelas. Skor tersebut berarti buku banduan yang dimaksud dinilai di atas baik (skor 3 = baik, dan 4 = amat baik), walau belum baik sekali.

Namun, mengapa rata-rata skor penilaian guru justru lebih rendah daripada yang diberikan dosen pakar penilaian? Hal itu tampaknya terkait dengan perbedaan pertanyaan yang diajukan. Dosen memberikan validasi yang terkait dengan aspek-aspek konseptual. Jadi, jika konsep yang diuraikan dalam buku panduan itu tepat, skor penilaian tentu saja tinggi. Di pihak lain, guru memberi- kan validasi yang terkait dengan aspekaspek pelaksanaannya dalam konteks penilaian pembelajaran di kelas. Jika konsep penilaian otentik itu sendiri belum dipahami dengan baik, atau model yang dikembangkan itu belum terbiasa dilaksanakan, mereka tentunya juga merasakan adanya unsur tidak mudah untuk melaksanakannya.

Hasil validasi yang diberikan oleh dosen pakar penilaian menunjukkan bahwa buku panduan tentang Model Penilaian Otentik dalam Pembelajaran Bahasa ini valid. Artinya, dilihat dari kacamata konseptual-keilmuan ia dapat dipertanggungjawabkan. Hal itu merupakan salah satu persyaratan utama untuk buku panduan yang harus terpenuhi sehingga jika dipergunakan untuk keperluan praktik pembelajaran di kelas tidak salah atau bahkan menjerumuskan. Sebaliknya, sebuah buku acuan yang baik harus memberikan manfaat bagi keperluan peningkatan pembelajaran. Terkait dengan pertanyaan apakah buku panduan ini memunyai kemanfaatan, ketiga pakar sepakat memberikan skor maksimal 4. Demikian juga para guru yang juga memberikan skor yang sama terhadap pertanyaan tersebut. Jadi, pengembangan buku panduan ini dinilai oleh para validator dapat memberikan manfaat yang tinggi.

Terhadap pertanyaan yang terkait dengan mudah-sulitnya penerapan model-model penilaian otentik diterapkan dalam penilaian pembelajaran bahasa di kelas, baik yang menyangkut aspek tes kompetensi berbahasa aktif reseptif maupun aktif produktif, para guru umumnya memberikan skor 3 . Hal itu menunjukkan beberapa kemungkinan, yaitu bahwa model-model itu belum akrab bagi mereka, model yang diberikan kurang bervariasi, atau model yang dicontohkan kurang mudah diikuti. Jika model yang ditunjukkan kurang bervariasi, sebenarnya guru dapat menam- 
bahkan atau mengembangkan sendiri karena pada bab sebelumnya telah diuraikan konsep dan berbagai bentuk penilaian otentik. Selain itu, jika sudah terbiasa menerapkan penilaian otentik pada berbagai tes proses, model ini pun akhirnya juga menjadi mudah.

Ada sejumlah saran dan masukan yang diberikan oleh pakar dan guru yang kalau dikategorikan akan meliputi aspek materi, bahasa, manfaat, dan kesalahan pengetikan. Secara umum dapat dikatakan bahwa saran dan masukan yang baik dan memang diperlukan dipakai untuk memperbaiki buku panduan. Misalnya, saran-saran penambahan model rubrik sebagai variasi dan penekanan bobot komponen yang dinilai, penggantian istilah-istilah pada komponen penilaian, pembetulan kesalahan penghitungan, sampai dengan pembetulan kesalahan penulisan (pengetikan) yang terjadi di sana-sini. Saran dan masukan tersebut bermanfaat dan diharapkan dapat meningkatkan kualitas produk buku panduan yang dikembangkan.

\section{SIMPULAN}

Seluruh rangkaian kegiatan penelitian pengembangan buku panduan ini dapat disimpulkan sebagai berikut. Pertama, pengembangan buku panduan yang berjudul Model Penilaian Otentik dalam Pembelajaran Bahasa sudah berhasil diselesaikan. Buku panduan yang dimaksud terdiri atas halaman depan (Kata Pengantar, Daftar Isi) dan tiga bab batang tubuh, Daftar Pustaka, Glosarium, dan Indeks. Bab I berisi landasan konseptual: KTSP, Pembelajaran Kontekstual (CTL, Contextual Teaching and Learning), dan Penilaian Otentik. Bab II berupa penerapan penilaian otentik dalam pembelajaran bahasa yang meliputi Penilaian Kompetensi Bahasa, Penilaian Kompetensi Berbahasa Aktif Reseptif (menyimak dan membaca), Penilaian
Kompeetnsi Berbahasa Aktif Produktif (berbicara dan menulis), dan Penilaian Kompetensi Bersastra. Bab III berisi pengolahan hasil penilaian otentik dan hal-hal yang terkait.

Kedua, hasil validasi yang dilakukan menunjukkan bahwa produk buku panduan yang dimaksud baik. Validasi konseptual yang diberikan pakar penilaian (tiga orang dosen) dengan skor rata-rata 3,90 dan guru mata pelajaran Bahasa Indonesia (lima orang ketua MGMP SMP di DIY) dengan skor ratarata 3,60 (skor 3 = baik dan 4 = amat baik). Hal itu dapat diartikan bahwa secara konseptual produk buku panduan tentang model penilaian otentik dalam pembelajaran bahasa yang dikembangkan dapat dipertanggungjawabkan secara konseptual. Selain itu, sebagai sebuah buku panduan, buku tersebut juga secara relatif mudah diterapkan dalam kegiatan pembelajaran bahasa di sekolah. Menurut para validator buku panduan tersebut juga amat bermanfaat untuk peningkatan kualitas pembelajaran bahasa.

\section{UCAPAN TERIMA KASIH}

Pada kesempatan ini kami ingin menyampaikan ucapan terima kasih kepada berbagai pihak yang telah memungkinkan terselenggaranya penelitian tahap kedua ini. Pertama, ucapan terima kami sampaikan kepada Direktur DP2M Dikti yang menyeponsori penelitian dengan menghibahkan dana lewat program penelitian Hibah Bersaing lewat Dipa Universitas Negeri Yogyakarta. Kedua, ucapan terima kasih kami sampaikan kepada Rektor UNY lewat Ketua Lembaga Penelitian UNY yang telah memfasilitasi penelitian ini sehingga semuanya dapat berjalan sesuai dengan ketentuan. Selanjutnya, ucapan terima kasih kami sampai kepada sejawat dosen dan para guru yang ketua MGMP Bahasa Indonesia SMP se-DIY 
yang telah bersedia menjadi validator, staf administrasi Lemlit UNY, dan berbagai pihak lain yang tidak dapat disebut satu per satu. Harapan kami penelitian ini ada manfaatnya kepada berbagai pihak yang terkait dan peningkatan pembelajaran bahasa di Indonesia.

\section{DAFTAR PUSTAKA}

Borg, Walter R. dan Meredith D. Gall. 1983. Educational Research: An Introduction. New York: Longman.

Brown, H. Douglas. 2004. Language Assessment, Principles and Classroom Practices. San Francisco: Longman.

Callison, Daniel. 2007. Authentic Assessment. Chicago: American Library Association.

Callison, Daniel. 2009. "Authentic Assessment" dalam American Assosiation of School Librarians. http:// www.ala.org/ala/mgrps/divs/ aasl/aaslpubsandjournals/slmrb/ editorschoiceb/infopower/selctcallison85.cfm, diakses 3 Oktober 2009.

Depdiknas. 2006. Pendekatan Kontekstual. Jakarta: Direktorat Jenderal Pendidikan Dasar dan Menengah, Direktorat Pendidikan Menengah Pertama.'
Gronlund, Norman F. 1985 (ed. Ke-5). Measurement and Evaluation in Teaching. New York: Macmilan Publishing Company.

Johsin, Elaine B. 2006. Contextual Teaching and Learning, Menjadikan Kegiatan Belajar-Mengajar Mengasyikkan dan Bermakna. Tanpa kota: MLC.

Mueller, John. 2008. Authentic Assessment Toolbox. North Central College, Naperville, http://jonathan.mueller.faculty.noctrl.edu/toolbox/ index.htm (Diunduh 27 Agustus 2008)

Peraturan Pemerintah.tth. Peraturan Pemerintah Republik Indonesia Nomor 19 Tahun 2005 tentang Standar Nasional Pendidikan.

Surapranata, Sumarna dan Muhammad Hatta. 2004. Penilaian Portofolio, Implementasi Kurikulum 2004. Jakarta: Rosda.

Wahyuni, Sri. 2009. Pengembangan Model Asesmen Otentik dalam Pembelajaran Keterampilan Berbahasa Indonesia Lisan di SMA. Malang: Disertasi Program Pascasarjana Universitas Negeri Malang. 